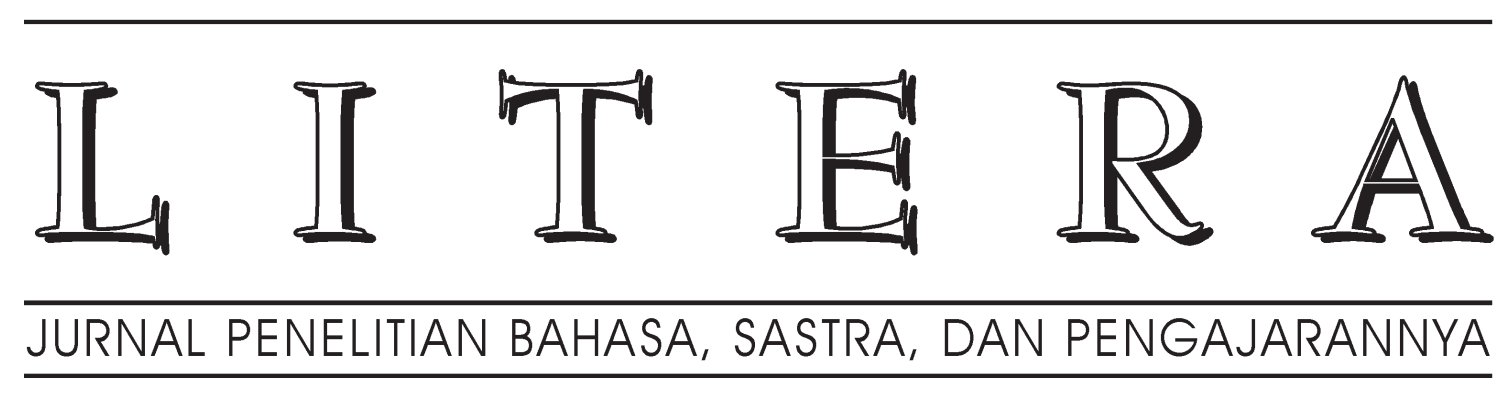

Berdasarkan SK Dirjen Dikti Nomor: 66b/DIKTI/Kep/2011, tanggal 9 September 2011 tentang Hasil Akreditasi Terbitan Berkala Ilmiah, LITERA dinyatakan sebagai Terbitan Berkala Ilmiah Terakreditasi, periode Agustus 2011 sampai dengan Agustus 2016 


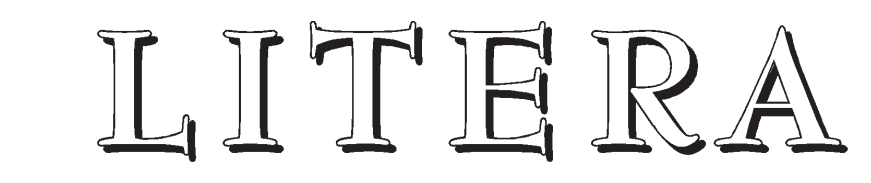

Jurnal Penelitian Bahasa, Sastra, dan Pengajarannya

Volume 12, Nomor 1, April 2013

* Tipe Argumen Wacana Argumentasi Tulis Siswa Sekolah Dasar Kelas Tinggi 146-158 Ahmad Ridhani 


\title{
TIPE ARGUMEN WACANA ARGUMENTASI TULIS SISWA SEKOLAH DASAR KELAS TINGGI
}

\author{
Ahmad Ridhani \\ FKIP Universitas Mulawarman Samarinda \\ email: ahmad_ridani@yahoo.com
}

\begin{abstract}
Abstrak
Penelitian ini bertujuan mendeskripsikan tipe argumen dalam wacana tulis siswa sekolah dasar. Sumber data adalah karangan siswa SD kelas tinggi di Sungai Kunjang Samarinda. Analisis data menggunakan model analisis isi komunikasi. Hasil penelitian menunjukkan terdapat tiga tipe argumen, yakni pendirian, pembuktian, dan penyimpulan. Argumen pendirian didasarkan pada fakta, interpretatif, dan evaluatif. Argumen pembuktian didasarkan pada pengamatan terhadap objek dan pengetahuan umum. Penyimpulan dilakukan secara induktif dan deduktif. Pengajuan pendirian, pembuktian, dan penyimpulan sebagai argument dalam wacana tulis erat kaitannya dengan pengetahuan awal yang tersimpan dalam memori jangka panjang pada setiap orang.
\end{abstract}

Kata kunci: wacana argumentasi, pendirian, pembuktian, penyimpulan

\section{TYPES OF ARGUMENTS IN WRITTEN ARGUMENTATIVE DISCOURSE BY ELEMENTARY SCHOOL STUDENTS IN THE UPPER GRADES}

\begin{abstract}
This study aims to describe the types of arguments in written discourse by elementary school students. The data sources were writing by elementary school students in the upper grades in Sungai Kunjang Samarinda. The data were analyzed using a communication content analysis model. The findings show that there are three types of arguments, i.e. opinion, proof, and conclusion. The opinion argument is based on facts, interpretation, and evaluation. The proving argument is based on an observation of an object and general knowledge. The concluding argument is inductively and deductively made. The use of opinion, proof, and conclusion as arguments in written discourse is related to the preliminary knowledge stored in every person's long-term memory.
\end{abstract}

Keywords: argumentative discourse, opinion, proof, conclusion

\section{PENDAHULUAN}

Argumentasi adalah proses membuat argumen ditujukan untuk membenarkan keyakinan, sikap, dan nilai sehingga dapat mempengaruhi orang lain (Warnick and Inch, 1994). Argumentasi merupakan salah satu bentuk proses persuasif. Perannya adalah untuk meyakinkan orang lain melalui alasan yang jelas dan bukti yang bagus bahwa sebuah nilai atau sudut pan- dang tertentu seharusnya diambil.

Tipe argumen adalah bentuk wacana yang ditandai oleh adanya pendirian bahwa sesuatu (kesimpulan) bisa dipercaya karena adanya sesuatu lainnya, misalnya data, premis, bukti yang dapat dipercaya (Brooks dan Warren, 1970). Tipe argumen bergantung pada argumen yang disampaikan untuk menyakinkan orang lain. Untuk menyakinkan orang lain agar ar- 
gumen yang disampaikan diterima orang lain diperlukan (1) pendirian, (2) pembuktian, dan (3) penyimpulan. Pendirian sebagai bagian dari unsur argumen adalah pendapat atau kesimpulan yang diambil berdasarkan bukti, jaminan, pengandaian, dan bantahan. Ada beberapa kata atau kelompok kata yang mengindikasikan adanya pendirian, di antaranya jadi, oleh karena itu, dengan demikian, dan simpulannya. Artinya, pernyataan setelah penandapenanda tersebut merupakan pendirian. Penggunaan penanda-penanda tersebut pada argumen memudahkan pembaca untuk menemukan posisi yang hendak dipertahankan oleh penulis. Bahkan, Santoso (1995) mengemukakan penalaran yang baik berusaha mencantumkan penanda-penanda itu secara eksplisit sehingga pembaca mudah memahami yang ditulis oleh penulis melalui penandapenanda itu (termasuk penanda alasan). Fisher (1993) dan Copy dan Cohen (1994) menyebut penanda-penanda tersebut dengan indikator kesimpulan.

Pembuktian merupakan inti bagi suatu argumen tertulis karena pembuktian dapat memberikan fakta-fakta atau alasan untuk membuat sebuah pendapat atau opini. Tanpa bukti, sebuah argumen berupa pendirian atau proposisi tidak bermakna. Dengan pembuktian, sebuah argumen menjadi kuat dan dapat digunakan untuk mengambil sebuah keputusan.

Pembuktian bagi penulis adalah untuk menunjukkan kepada pembaca bahwa bukti tersebut mendukung argumen yang ditulis. Ketika penulis memperkenalkan atau menunjukkan bukti, maka penulis harus menunjukkan kepada para pembaca mengapa bukti ini mendukung sebuah argumen. Bukti tersebut harus dianalisis dan diinterpretasikan.

Penyimpulan adalah proses mendapatkan suatu proposisi yang ditarik dari satu atau lebih proposisi (Mehra dan Burhan, 1988). Penyimpulan dilakukan atas lebih dari satu proposisi dan kalau dinyatakan pada bahasa disebut argumen. Selanjutnya dijelaskan pula bahwa penyimpulan pada umumnya dilakukan secara deduktif dan induktif. Penyimpulan deduktif, simpulan tidak mungkin lebih umum sifatnya daripada premispremisnya sedangkan secara induktif, konklusi pasti lebih umum daripada premis-premisnya. Penyimpulan deduktif mungkin dilakukan secara langsung atau tak langsung. Penyimpulan langsung adalah proses deduktif yang simpulannya ditarik dari satu premis saja, sedangkan simpulan tak langsung adalah simpulan yang ditarik dari dua premis atau lebih.

Tulisan ini dipaparkan untuk mendeskripsikan dan menjelaskan tipe argumen wacana argumentasi tulis siswa sekolah dasar kelas tinggi. Isi tulisan ini bagian dari hasil penelitian dalam disertasi berjudul wacana argumentasi tulis siswa sekolah dasar kelas tinggi. Secara khusus dipaparkan tipe argumen mencakup (1) pendirian, (2) pembuktian, dan (3) penyimpulan dalam WAT siswa SD kelas tinggi.

\section{METODE}

Penelitian ini menggunakan analisis isi komunikasi. Komunikasi dalam wacana argumentasi diasumsikan memiliki tipe argumen yang digunakan pengargumen untuk mempengaruhi dan meyakinkan orang lain agar mudah memahami dan mengerti isi pesan yang disampaikan.

Data penelitian ini adalah karangan siswa SD kelas tinggi. Sumber data adalah siswa SD kelas tinggi, yakni siswa kelas IV, V, dan VI SDN 006 Sungai Kunjang, Kota Samarinda. Analisis data penelitian ini menggunakan model analisis isi komunikasi diadaptasi dari Holsti (1969) dan Krippendorff (1980). Data dianalisis dengan langkah-langkah, yaitu (1) pengumpulan data, (2) penyajian data, (3) reduksi data, dan (4) penarikan simpulan dan verifikasi. 


\section{HASIL PENELITIAN}

Hasil penelitian menunjukkan bahwa tipe argumen wacana argumentasi siswa sekolah dasar kelas tinggi berupa pendirian tentang fakta, pembuktian berdasarkan pengamatan dan pengalaman, serta penyimpulan induktif dan deduktif menunjukkan kekonkretan berpikir siswa usia sekolah dasar. Tipe argumen diuraikan sebagai berikut.

\section{Tipe Argumen Pendirian}

Pendirian dalam WAT siswa SD kelas tinggi didasarkan pada (1) pendirian faktual, (2) pendirian interpretatif, dan (3) pendirian evaluatif.

\section{Pendirian Faktual}

Berdasarkan temuan data, pendirian faktual WAT siswa SD kelas tinggi ditandai dengan pernyataan-pernyataan faktual dari data-data konkret. Pernyataan faktual ini disimpulkan dari data konkret yang dominan, misalnya ketika siswa berada di perempatan lampu merah, dia melihat adanya fakta beberapa anakanak mendekati mobil sambil membawa sesuatu, ia menyimpulkan bahwa anakanak sedang mencari uang dengan cara menjual koran di jalanan. Hal ini dapat dilihat pada data (1) s.d. (3) berikut.

(1) Anak-anak sedang mencari uang dengan cara menjual koran di jalanan (4.a.013).

(2) Di sebagian wilayah Indonesia sering terjadi musibah banjir, khususnya di daerah-daerah Jakarta, Sulawesi, Sumatra, Jawa dan lain sebagainya (5.a.47).

(3) Hujan yang sangat deras akan menyebabkan banjir makin tinggi, sampah yang berserakan di pinggir jalan atau trotoar. Tidak ada korban jiwa pada peristiwa ini (4.a.011).

Pendirian pada data (1) "Anak-anak sedang mencari uang dengan cara men- jual koran di jalanan" termasuk pendirian faktual. Subjek penelitian mengajukan pendirian faktual berdasarkan hasil pengamatan dan pengalaman mereka ketika ia berada di perempatan lampu merah, ia melihat adanya fakta beberapa anak-anak mendekati mobil sambil membawa sesuatu, ia menyimpulkan bahwa anak-anak sedang mencari uang dengan cara menjual koran di jalanan. Pendirian faktual didasarkan adanya informasi lama, yaitu beberapa anak-anak berada di perempatan lampu merah. Berdasarkan informasi lama itu, subjek penelitian menyimpulkan bahwa anakanak sedang mencari uang dengan cara menjual koran di jalanan. Anak-anak sedang mencari uang dengan cara menjual koran di jalanan sebagai informasi baru. Dengan demikian, WAT yang dihasilkan subjek penelitian berisi pendirian faktual berdasarkan hasil pengamatan dan pengalaman mereka. Pendirian faktual yang diajukan berdasarkan fakta yang diperoleh dari informasi lama (beberapa anak-anak berada di perempatan lampu merah) untuk memperoleh informasi baru (anak-anak sedang mencari uang dengan cara menjual koran di jalanan) sebagai sebuah kesimpulan.

Pendirian pada data (2) "Di sebagian wilayah Indonesia sering terjadi musibah banjir, khususnya di daerah-daerah Jakarta, Sulawesi, Sumatra, Jawa dan lain sebagainya" termasuk pengajuan pendirian faktual. Subjek penelitian mengajukan pendirian faktual berdasarkan hasil pengamatan dan pengalaman mereka ketika ia melihat adanya fakta musim hujan di wilayah Indonesia, ia menyimpulkan bahwa di sebagian wilayah Indonesia sering terjadinya musibah banjir, khususnya di daerah-daerah Jakarta, Sulawesi, Sumatra, Jawa dan lain sebagainya. Pengajuan pendirian faktual didasarkan adanya informasi lama, yaitu musim hujan di wilayah Indonesia. Berdasarkan informasi lama itu, subjek penelitian menyimpulkan 
sebagai informasi baru, yaitu di sebagian wilayah Indonesia sering terjadinya musibah banjir, khususnya di daerahdaerah Jakarta, Sulawesi, Sumatra, Jawa dan lain sebagainya. Dengan demikian, WAT yang dihasilkan subjek penelitian berisi pendirian faktual berdasarkan hasil pengamatan dan pengalaman mereka. Pendirian faktual yang diajukan berdasarkan fakta yang diperoleh dari informasi lama (musim hujan di wilayah Indonesia) untuk memperoleh informasi baru (di sebagian wilayah Indonesia sering terjadinya musibah banjir, khususnya di daerah-daerah Jakarta, Sulawesi, Sumatra, Jawa dan lain sebagainya) sebagai sebuah kesimpulan.

Pendirian pada data (3) "Hujan yang sangat deras akan menyebabkan banjir makin tinggi, sampah yang berserakan di pinggir jalan atau trotoar. Tidak ada korban jiwa pada peristiwa ini" termasuk pengajuan pendirian faktual. Subjek penelitian mengajukan pendirian faktual berdasarkan hasil pengamatan ketika melihat adanya fakta hujan yang sangat deras, ia menyimpulkan bahwa hujan yang sangat deras akan menyebabkan banjir makin tinggi, sampah yang berserakan di pinggir jalan atau trotoar. Tidak ada korban jiwa pada peristiwa ini. Pendirian faktual didasarkan adanya informasi lama, yaitu hujan yang sangat deras. Berdasarkan informasi lama itu, subjek penelitian menyimpulkan hujan yang sangat deras akan menyebabkan banjir makin tinggi, sampah yang berserakan di pinggir jalan atau trotoar sebagai informasi baru. Dengan demikian, WAT yang ditulis subjek penelitian berisi pengajuan pendirian faktual berdasarkan hasil pengamatan mereka. Pendirian faktual yang diajukan berdasarkan fakta yang diperoleh dari informasi lama (hujan yang sangat deras) untuk memperoleh informasi baru (hujan yang sangat deras akan menyebabkan banjir makin tinggi, sampah yang berserakan di pinggir jalan atau trotoar) sebagai sebuah kesimpulan.

\section{Pendirian Interpretatif}

Berdasarkan temuan data, pengajuan pendirian interpretasiWAT siswa SD kelas tinggi ditandai dengan pernyataanpernyataan faktual yang dinterpretasikan dari data-data konkret. Pernyataan interpretasi ini disimpulkan dari data konkret yang dominan, misalnya ketika musim hujan tiba, hujan sangat lebat, subjek penelitian melihat adanya fakta barangbarang terendam banjir, ia menyimpulkan bahwa semua barang-barang terendam banjir. Hal ini dapat dilihat pada data (4) s.d (6) berikut.

(4) Semua barang-barang terendam banjir. Barang-barang yang ada di rumah semua rusak, seperti lemari, meja, kursi, meja belajar, tempat tidur, dan lain-lainnya (5.a.50)

(5) Semua ternak milik petani tidak dapat minum karena air sungai atau air sumur kering dan kosong akibat kemarau yang sangat panjang dan tidak ada hujan turun (5.b.110).

(6) Jika hujan deras, mereka harus menghentikan pekerjaannya dan melanjutkan keesokan harinya untuk berjualan koran (6a.82).

Pendirian pada data (4) "Semua barang-barang terendam banjir. Barangbarang yang ada di rumah semua rusak, seperti lemari, meja, kursi, meja belajar, tempat tidur, dan lain-lainnya" termasuk pendirian interpretatif. Subjek penelitian mengajukan pendirian interpretatif berdasarkan hasil pengamatan dan pengalaman mereka ketika ia melihat adanya fakta terjadinya peristiwa banjir, ia menyimpulkan bahwa semua barang-barang terendam banjir. Pengajuan pendirian interpretatif didasarkan adanya informasi lama, yaitu terjadinya peristiwa banjir. Berdasarkan informasi lama itu, subjek penelitian menyimpulkan bahwa semua barang-barang terendam banjir akibatnya barang-barang itu menjadi rusak sebagai informasi baru. Hal 
itu diinterpretasikan bahwa akibat banjir, semua barang-barang terendam banjir. Barang-barang yang terendam banjir itu semuanya rusak, misalnya lemari, meja, kursi, meja belajar, tempat tidur, dan lainlainnya. Dengan demikian, WAT yang ditulis subjek penelitian berisi pengajuan pendirian interpretatif berdasarkan hasil pengamatan dan pengalaman mereka. Pendirian interpretatif yang diajukan berdasarkan fakta yang diperoleh dari informasi lama (terjadinya peristiwa banjir) untuk memperoleh informasi baru (semua barang-barang terendam banjir akibatnya barang-barang itu menjadi rusak) sebagai sebuah kesimpulan.

Pendirian pada data (5) "Semua ternak milik petani tidak dapat minum karena air sungai atau air sumur kering dan kosong akibat kemarau yang sangat panjang dan tidak ada hujan turun" termasuk pendirian interpretatif. Subjek penelitian mengajukan pendirian interpretatif berdasarkan hasil pengamatan dan pengalaman mereka ketika ia melihat adanya fakta terjadinya kemarau yang sangat panjang dan tidak ada hujan turun, ia menyimpulkan bahwa semua ternak milik petani tidak dapat minum karena air sungai atau air sumur kering dan kosong. Pengajuan pendirian interpretatif didasarkan adanya informasi lama, yaitu terjadinya kemarau yang sangat panjang dan tidak ada hujan turun. Berdasarkan informasi lama itu, subjek penelitian menyimpulkan bahwa semua ternak milik petani tidak dapat minum karena air sungai atau air sumur kering dan kosong sebagai informasi baru. Dengan demikian, WAT yang ditulis subjek penelitian berisi pengajuan pendirian interpretatif berdasarkan hasil pengamatan dan pengalaman mereka. Pendirian interpretatif yang diajukan berdasarkan fakta yang diperoleh dari informasi lama (terjadinya kemarau yang sangat panjang dan tidak ada hujan turun) untuk memperoleh informasi baru (semua ternak milik petani tidak dapat minum karena air sungai atau air sumur kering dan kosong) sebagai sebuah kesimpulan.

Pendirian pada data (6) "Jika hujan deras, mereka harus menghentikan pekerjaannya dan melanjutkan keesokan harinya untuk berjualan koran" termasuk pendirian interpretatif. Subjek penelitian mengajukan pendirian interpretatif berdasarkan hasil pengamatan dan pengalaman mereka ketika ia melihat adanya fakta terjadinya hujan deras, ia menyimpulkan bahwa jika hujan deras, mereka harus menghentikan pekerjaannya. Pengajuan pendirian interpretatif didasarkan adanya informasi lama, yaitu terjadinya hujan deras. Berdasarkan informasi lama itu, subjek penelitian menyimpulkan bahwa jika hujan deras, mereka harus menghentikan pekerjaannya sebagai informasi baru. Hal itu diinterpretasikan bahwa jika hujan deras, mereka harus menghentikan pekerjaannya, maka mereka akan melanjutkan keesokan harinya untuk berjualan koran. Dengan demikian, WAT yang ditulis subjek penelitian berisi pengajuan pendirian interpretatif berdasarkan hasil pengamatan dan pengalaman mereka. Pendirian interpretatif yang diajukan berdasarkan fakta yang diperoleh dari informasi lama (terjadinya hujan deras) untuk memperoleh informasi baru (jika hujan deras, mereka harus menghentikan pekerjaannya) sebagai sebuah kesimpulan.

\section{Tipe Argumen Pembuktian}

Pembuktian dilakukan untuk mendukung sebuah argumen agar gagasan yang disampaikan dapat diterima oleh mitratutur. Subjek penelitian mengajukan pembuktian dalam WAT berdasarkan pengamatan terhadap objek dan berdasarkan pengetahuan umum.

\section{Pembuktian Berdasarkan Hasil Pengama- tan \\ Pembuktian berdasarkan hasil pengamatan dilakukan oleh seseorang melalui kegiatan mendengar, melihat,}


menyentuh, mencium, atau merasakannya. Berdasarkan temuan data, pembuktian dalam WAT siswa SD kelas tinggi berdasarkan pengamatan terhadap objek melalui pembuktian untuk mendukung sebuah argumen agar gagasan yang disampaikan dapat diterima oleh pembacanya, seperti tampak pada data (7) s.d.

(8) berikut.

(7) Kebakaran itu sangat gede dan warga panik takut apinya merambat ke rumahnya (4.a.003).

(8) Kemarin saya melihat orang-orang sedang berdemo. Ada yang membawa spanduk, toak, ikat kepala dan lainlain (4.a.009).

Pembuktian pada data (7) "Kebakaran itu sangat gede dan warga panik takut apinya merambat ke rumahnya" termasuk pengajuan bukti berdasarkan pengamatan. Subjek penelitian mengajukan bukti WAT berdasarkan pengamatan terhadap kebakaran yang terjadi pada hari Minggu ketika subjek dan keluarganya pergi ke Citra Niaga Samarinda. Subjek melihat kebakaran di Karang Asam di dekat lapangan Samarinda Super Blok. Subjek menyatakan bahwa kebakaran itu sangat gede dan warga panik takut apinya merambat ke rumahnya. Dengan demikian, WAT yang dihasilkan subjek penelitian berisi pembuktian berdasarkan pengamatan karena proposisi yang diajukan sebagai bukti untuk menjelaskan adanya fakta adanya kebakaran agar pembaca dapat menerima apa yang disampaikannya.

Pembuktian pada data (8) "Ada yang membawa spanduk, toak, ikat kepala dan lain-lain" termasuk pengajuan bukti berdasarkan pengamatan. Subjek penelitian mengajukan bukti WAT berdasarkan pengamatan terhadap orang-orang yang sedang berdemo. Pembuktian mereka itu mengadakan demo, pendemo itu membawa spanduk, toak, ikat kepala, dan lain-lain. Ada yang berdiri di atas truk sambil berteriak dengan tolak atau bi- asanya disebut dengan instruktur. Dengan demikian, WAT yang dihasilkan subjek penelitian berisi pembuktian berdasarkan pengamatan karena proposisi yang diajukan sebagai bukti untuk menjelaskan adanya fakta tertentu agar pembaca dapat menerima apa yang disampaikannya.

\section{Pembuktian Berdasarkan Pengetahuan Umum}

Berdasarkan temuan data, WAT yang dihasilkan subjek penelitian berisi pembuktian berdasarkan pengetahuan umum terhadap objek melalui pembuktian untuk mendukung sebuah argumen agar gagasan yang disampaikan dapat diterima oleh pembacanya, seperti tampak pada data (9) s.d. (10) berikut.

(9) Setelah selesai gotong royong, mereka pulang dengan senang hati karena desanya kelihatan rapi dan sejuk (4.a.007)

(10) Di Samarinda sering terjadi banjir apabila hujan terus menerus turun. Terutama di Jl. P. Antasari sering terjadi banjir hingga mencapai lutut orang dewasa (06.a.094).

Pembuktian pada data (9) "Setelah selesai gotong royong, mereka pulang dengan senang hati karena desanya kelihatan rapi dan sejuk" termasuk pembuktian berdasarkan pengamatan. Subjek penelitian mengajukan bukti WAT berdasarkan pengetahuan umum. Setelah melaksanakan kegiatan gotong royong, setiap warga pulang ke rumah masingmasing. Mereka tentu merasa senang karena desa mereka kelihatan sejuk dan rapi. Hal yang secara umum dilakukan dan dialami setiap warga yang melakukan kegiatan gotong royong juga dialami oleh warga desa Melati, setelah selesai gotong royong, mereka pulang dengan senang hati karena desanya kelihatan rapi dan sejuk. Dengan demikian, WAT yang dihasilkan subjek penelitian berisi pembuktian berdasarkan pengetahuan umum 
karena proposisi yang diajukan sebagai bukti untuk menjelaskan adanya fakta tertentu agar pembaca dapat menerima apa yang disampaikannya.

Pembuktian pada data (10) "Di Samarinda sering terjadi banjir apabila hujan terus menerus turun. Terutama di Jl. P. Antasari sering terjadi banjir hingga mencapai lutut orang dewasa" termasuk pembuktian berdasarkan pengetahuan umum. Subjek penelitian mengajukan bukti WAT berdasarkan pengetahuan umum. Jalan Pangeran Antasari, kota Samarinda secara umum sudah dikenal dan dirasakan oleh warga kota sering terjadi banjir walaupun hanya satu jam. Hal yang wajar jika subjek menyatakan bahwa di Samarinda sering terjadi banjir apabila hujan terus menerus turun. Terutama di Jl. P. Antasari sering terjadi banjir hingga mencapai lutut orang dewasa. Dengan demikian, WAT yang dihasilkan subjek penelitian berisi pembuktian berdasarkan pengetahuan umum karena proposisi yang diajukan sebagai bukti untuk menjelaskan adanya fakta tertentu agar pembaca dapat menerima apa yang disampaikannya.

\section{Tipe Argumen Penyimpulan}

Unsur penting yang terdapat pada sebuah argumen adalah penyimpulan. Penyimpulan adalah proses mendapatkan suatu proposisi yang ditarik dari satu atau lebih proposisi. Berdasarkan temuan data, penyimpulan WAT siswa SD kelas tinggi dilakukan secara induktif dan deduktif. Pada penyimpulan induktif, simpulannya lebih umum daripada premis-premisnya. Sedangkan penyimpulan deduktif, simpulan tidak mungkin lebih umum sifatnya daripada premis-premisnya. Berikut dipaparkan penyimpulan WAT siswa SD kelas tinggi secara induktif dan deduktif.

\section{Penyimpulan Induktif}

Penyimpulan induktif menggunakan prosedur penyimpulan yang dimulai dengan pengajuan bukti-bukti yang berkaitan dengan topik (contoh, fakta, pengalaman, laporan, atau data statistik) dan diakhiri dengan simpulan.Pada penyimpulan induktif, simpulannya lebih umum daripada premis-premisnya.

Berdasarkan temuan data, WAT yang dihasilkan siswa SD kelas tinggi berisi penyimpulan induktif berdasarkan buktibukti yang diajukan terhadap objek untuk mendukung sebuah argumen agar dapat diterima oleh pembacanya, seperti tampak pada data (11) s.d. (12) berikut.

(11) Lihat anak-anak itu! Mereka menghabiskan tenaga untuk mencari uang, bersekolah dan makan sehari-hari untuk memenuhi kebutuhan mereka sehari-hari. Dengan berjualan koranlah mereka bisa hidup (4.a.033).

(12) Peristiwa banjir disebabkan oleh orang-orang yang membuang sampah sembarangan di sungai dan menebang pohon secara liar dan tanpa izin. Oleh karena itu kita tidak boleh buang sampah sembarangan apalagi menebang pohon sebarangan (4.a.001).

Penyimpulan pada data (12) "Lihat anak-anak itu! Mereka menghabiskan tenaga untuk mencari uang, bersekolah dan makan sehari-hari untuk memenuhi kebutuhan mereka sehari-hari.Dengan berjualan koranlah mereka bisa hidup." Data yang diajukan tersebut termasuk penyimpulan induktif. Subjek penelitian melakukan penarikan simpulan induktif WAT berdasarkan bukti-bukti yang diajukan. Bukti-bukti yang diajukan, yaitu (1) mereka menghabiskan tenaga untuk mencari uang, (2) mereka bersekolah untuk memenuhi kebutuhan mereka sehari-hari, dan (3) mereka makan sehari-hari dengan berjualan koran. Berdasarkan ketiga bukti yang dikemukakan, subjek penelitian menarik kesimpulan bahwa dengan berjualan koran mereka bisa hidup. Dengan demikian, WAT yang dihasilkan subjek penelitian berisi penyimpulan induktif 
berdasarkan bukti-bukti yang diajukan terhadap objek untuk mendukung sebuah argumen agar dapat diterima oleh pembacanya.

Penyimpulan pada data (12)" Peristiwa banjir disebabkan oleh orang-orang yang membuang sampah sembarangan di sungai dan menebang pohon secara liar dan tanpa izin. Oleh karena itu, kita tidak boleh membuang sampah sembarangan apalagi menebang pohon sembarangan." Data yang diajukan termasuk penyimpulan induktif. Subjek penelitian melakukan penarikan simpulan induktif WAT berdasarkan bukti-bukti yang diajukan. Bukti-bukti yang diajukan, yaitu (1) peristiwa banjir disebabkan oleh orang-orang yang membuang sampah sembarangan di sungai, (2) peristiwa banjir disebabkan oleh orang-orang yang membuang sampah sembarangan, dan (3) peristiwa banjir disebabkan oleh orangorang yang menebang pohon secara liar dan tanpa izin. Berdasarkan ketiga bukti yang dikemukakan, Subjek penelitian menarik kesimpulan bahwa kita tidak boleh membuang sampah sembarangan apalagi menebang pohon sembarangan. Dengan demikian, WAT yang dihasilkan subjek penelitian berisi penyimpulan induktif berdasarkan bukti-bukti yang diajukan terhadap objek untuk mendukung sebuah argumen agar dapat diterima oleh pembacanya.

\section{Penyimpulan Deduktif}

Penyimpulan deduktif, simpulannya tidak akan lebih umum daripada premispremisnya. Premis adalah proposisiproposisi yang digunakan untuk penarikan simpulan, sedangkan simpulan ialah proposisi yang menyatakan hasil inferensi yang dilakukan berdasarkan proposisiproposisi yang menjadi premis-premis suatu inferensi.

Berdasarkan temuan data, WAT yang dihasilkan subjek penelitian berisi penyimpulan deduktif WAT berdasarkan proposisi-proposisi yang menjadi premispremis suatu inferensi untuk mendukung sebuah argumen agar dapat diterima oleh pembacanya, seperti tampak pada data (13) s.d. (14) berikut.

(13) Kebakaran di Samarinda terus bertambah. Kebakaran di Samarinda membuat jalan macet. Rumah-rumah warga Kota Samarinda hagus terbakar. Warga Kota Samarinda harus kehilangan rumah-rumah mereka. Peristiwa ini bisa disebabkan oleh kelalaian ataupun gara-gara anakanak bermain petasan (5.a.41).

(14) Banjir bisa meresahkan warga sekitar. Kendaraan berhenti karena terkena banjir, orang-orang berusaha mengungsi karena rumah mereka terendam banjir. Banjir bisa disebabkan oleh orang membuang sampah sembarangan dan luapan air sungai. Banjir biasanya terjadi pasa musim hujan. Hujan yang turun terusmenerus pada suatu daerah dapat berubah menjadi banjir (5.a.039).

Penyimpulan pada data (13) "Kebakaran di Samarinda terus bertambah. Kebakaran di Samarinda membuat jalan macet. Rumah-rumah warga Kota Samarinda hagus terbakar. Warga Kota Samarinda harus kehilangan rumah-rumah mereka. Peristiwa ini bisa disebabkan oleh kelalaian ataupun gara-gara anak-anak bermain petasan". Data yang diajukan tersebut termasuk penyimpulan deduktif. Subjek penelitian melakukan penarikan simpulan deduktif WAT berdasarkan proposisi-proposisi yang menjadi premispremis suatu inferensi untuk mendukung sebuah argumen agar dapat diterima oleh pembacanya. Simpulan yang disampaikan yaitu kebakaran di Samarinda terus bertambah. Peristiwa kebakaran di Kota Samarinda dapat disebabkan oleh kelalaian ataupun gara-gara anak-anak bermain petasan. Akibatnya (1) jalan-jalan macet, (2) rumah-rumah warga hangus terbakar, 
dan (3) warga Kota Samarinda harus kehilangan rumah-rumah mereka. Dengan demikian, WAT yang dihasilkan subjek penelitian berisi penyimpulan deduktif dengan cara mengajukan kesimpulan secara umum dari hasil berpikir logis dengan menyampaikan berbagai akibat sebagai bukti empirik terhadap objek untuk mendukung sebuah argumen agar dapat diterima oleh pembacanya.

Penyimpulan pada data (14) "Banjir bisa meresahkan warga sekitar. Kendaraan berhenti karena terkena banjir, orang-orang berusaha mengungsi karena rumah mereka terendam banjir. Banjir bisa disebabkan oleh orang membuang sampah sembarangan dan luapan air sungai. Banjir biasanya terjadi pasa musim hujan. Hujan yang turun terus-menerus pada suatu daerah dapat berubah menjadi banjir". Data yang diajukan tersebut termasuk penyimpulan deduktif. Subjek penelitian melakukan penarikan simpulan deduktif WAT berdasarkan proposisiproposisi yang menjadi premis-premis suatu inferensi untuk mendukung sebuah argumen agar dapat diterima oleh pembacanya. Simpulan yang disampaikan yaitu banjir bisa meresahkan warga sekitar. Banjir bisa disebabkan oleh orang membuang sampah sembarangan dan luapan air sungai. Akibatnya, kenderaan berhenti dan orang-orang berusaha mengungsi. Kendaraan berhenti karena terkena banjir. Orang-orang berusaha mengungsi karena rumah mereka terendam banjir. Dengan demikian, WAT yang dihasilkan subjek penelitian berisi penyimpulan deduktif dengan cara mengajukan kesimpulan secara umum dari hasil berpikir logis dengan menyampaikan sebab, akibat, dan alasan sebagai bukti empirik terhadap objek untuk mendukung sebuah argumen agar dapat diterima oleh pembacanya.

\section{PEMBAHASAN}

Temuan tentang pengajuan pendirian faktual sesuai dengan pendapat Warnick and Inch (1994:64) dan Dawud (1998:28) mengemukakan bahwa pendirian tentang fakta berupa pernyataan simpulan tentang kondisi atau hubungan masa lalu, kini, dan akan datang. Dalam penelitian ini, subjek penelitian mengajukan pendirian faktual tentang (1) anak jalanan berjualan koran di jalanan, (2) peristiwa kebakaran di Samarinda, dan (3) banyak hewan mati karena musim kemarau didasarkan atas kondisi faktual yang ada di sekitar mereka yang terjadi sepanjang waktu. Temuan tersebut juga sesuai dengan pendapat Keraf (2010:6) bahwa untuk membuktikan kebenaran dalam sebuah kesimpulan, harus dicari dan diuji fakta-fakta yang dijadikan landasan untuk menyusun sebuah kesimpulan. Fakta-fakta yang dikemukakan subjek penelitian mengemukakan berbagai fakta untuk membuktikan kebenaran dalam sebuah kesimpulan yang disampaikan agar pembaca dapat menerima fakta yang dikemukakan.

Temuan penelitian pembuktian berdasarkan hasil pengamatan sesuai dengan pendapat Keraf (2010:11) bahwa banyak pernyataan-pernyataan yang diberikan oleh seseorang didasarkan pada observasi yang telah dilakukan. Fakta-fakta yang diajukan sebagai bukti jika belum memadai perlu dilakukan observasi agar lebih meyakinkan dirinya sendiri dan sekaligus dapat menggunakan hasil observasi dalam usaha untuk meyakinkan para pembaca.

Temuan tentang pengajuan penilaian yang diekspresikan oleh subjek penelitian berkaitan erat dengan penilaian tentang sebuah fenomena ekspresif seseorang. Hal itu sesuai dengan pendapat Santoso (2002:300) bahwa nilai ekspresif berhubungan dengan identitas subjek dan identitas sosial yang selanjutnya berhubungan dengan nilai-nilai subjektif. Berkaitan dengan nilai ekspresif tersebut, ada dua macam evaluasi, yaitu evaluasi positif dan evaluasi negatif yang ditandai 
dengan kosakata yang diekspresikan. Subjek cenderung mengekspresikan evaluasi negatif daripada evaluasi positif.

Temuan tentang pendirian faktual, interpretatif, dan evaluatif yang dihasilkan oleh subjek penelitian menunjukkan bahwa WAT yang ditulis subjek penelitian berisi pengajuan pendirian faktual, interpretatif, dan evaluatif. Pendirian dihasilkan melebihi dari standar kompetensi yang disarankan dalam kurikulum satuan pendidikan (KTSP) matapelajaran bahasa Indonesia (BI). Standar kompetensi pada matapelajaran BI dinyatakan bahwa siswa SD kelas V diharapkan memiliki kemampuan mengungkapkan pikiran, perasaan, informasi, dan fakta secara tertulis pada bentuk ringkasan, laporan, dan puisi bebas (Depdiknas, 2006). Kenyataannya, WAT yang dihasilkan siswa SD kelas IV, $\mathrm{V}$, dan VI tidak sekadar mengemukakan fakta saja tetapi telah mengemukakan sejumlah fakta berupa pendirian faktual, interpretatif, dan evaluatif.

Temuan tentang penyimpulan induktif yang didahului dengan pengajuan bukti-bukti yang berkaitan dengan fakta atau pengalaman dan diakhiri dengan simpulan. Hal itu sesuai dengan pendapat Vygotsky (1962) menyatakan bahwa anakanak memperoleh pengetahuan melalui interaksi dengan orang lain dan lingkungan belajarnya. Melalui interaksi sosial melalui lingkungan belajar tersebut, anakanak secara terus menerus mengonstruksi pemahaman berdasarkan pengetahuan yang dimiliki ketika mereka berkomunikasi. Mereka mengonstruksi pengetahuan dengan berpartisipasi aktif dalam pembelajaran dan memaknainya melalui pengalaman nyata. Mereka berkesempatan untuk menemukan dan menerapkan pendapat mereka sendiri dan orang lain untuk mencapai tingkat pemahaman yang lebih tinggi. Mereka belajar melalui kehidupan nyata dengan cara mengeksplorasi dan menemukan sesuatu yang baru. Dengan demikian, WAT yang di- hasilkan subjek penelitian berisi penyimpulan induktif berdasarkan bukti-bukti yang diajukan terhadap objek dari hasil interaksi dengan lingkungan sekitarnya yang disampaikan dalam sebuah argumen agar dapat diterima oleh pembacanya.

Temuan tentang penyimpulan deduktif dengan cara mengajukan kesimpulan secara umum dari hasil berpikir logis dengan menyampaikan berbagai akibat sebagai bukti empirik terhadap objek sesuai dengan pendapat Chomsky (1965) bahwa seseorang dalam belajar bahasa bukanlah pembentukan kebiasaan yang mendapat rangsangan dari luar, melainkan di dalam diri seseorang sudah terdapat kapasistas belajar bahasa yang dibawa sejak lahir, yaitu aspek berbahasa yang kreatif. Dia percaya bahwa tidak ada cara untuk memahami pikiran manusia tanpa memahami kemampuan kreativitas dalam penggunaan bahasa.

Temuan tentang penyimpulan sesuai dengan pendapat Mehra dan Burhan (1988) menyatakan bahwa penyimpulan adalah proses mendapatkan suatu proposisi yang ditarik dari satu atau lebih proposisi. Dengan demikian, WAT yang dihasilkan subjek penelitian berisi penyimpulan induktif dan deduktif. Penyimpulan ditandai adanya proses untuk mendapatkan suatu proposisi yang ditarik dari satu proposisi atau lebih.

Berdasarkan data (1) s.d. (14) dapat disimpulkan bahwa WAT yang dihasilkan subjek penelitian berisi pengajuan argumen, yaitu (1) pendirian, (2) pembuktian, dan (3) penyimpulan. Hal itu sesuai dengan Warnick dan Inch (1994) dan Dawud (2010:11) yang menyatakan bahwa argumen sebagai salah satu jenis komunikasi memiliki tiga unsur berikut. Pertama, pendirian, yakni pendirian yang diekspresikan atau simpulan yang diinginkan oleh penutur (pembicara atau penulis) agar diterima oleh penuturnya (pendengar atau pembaca). Kedua, bukti yaitu fakta atau kondisi yang secara objek- 
tif dapat diamati, keyakinan atau pendirian yang secara umum telah diterima kebenarannya, atau simpulan yang dimantapkan sebelumnya. Ketiga, penyimpulan, yakni upaya untuk mempengaruhi orang lain. Upaya tersebut dilakukan dengan menyusun simpulan agar orang lain menerima atau menolaknya. Dengan demikian, untuk meyakinkan orang lain, subjek penelitian mengajukan pendirian, bukti, penarikan simpulan pada WAT agar argumen yang disampaikan diterima oleh orang lain.

Temuan pengajuan pendirian dalam penelitian ini memiliki persamaan dan perbedaan dengan penelitian Dawud (1998). Persamaan terletak pada temuan pendirian faktual. Kedua penelitian ini mengungkapan adanya pendirian faktual yang disimpulkan dari data konkret yang dominan. Pendirian faktual yang ditemukan Dawud (1998) bersumber dari data lisan. Pendirian faktual yang ditemukan dalam penelitian ini bersumber dari data tulis. Pengajuan pendirian dalam penelitian ini di samping adanya pengajuan pendirian faktual juga ditemukan pendirian interpretatif dan pendirian evaluatif. Kedua pendirian ini berbeda dengan penelitian Dawud (1998).

Temuan penyimpulan induktif dan deduktif sesuai dengan pendapat Poespoprodjo dan Gilarso (1999:22) menyatakan bahwa sesuai dengan titik pangkal dalam proses pemikiran dapat dibedakan dua jalan atau pola dasar, yaitu induksi dan deduksi. Induksi merujuk pada proses pemikiran di dalam akal seseorang dari pengetahuan tentang kejadian/peristiwa/ hal-hal yang lebih konkret dan khusus untuk menyimpulkan pengetahuan yang lebih umum. Deduktif merujuk pada proses pemikiran di dalam akal seseorang dari pengetahuan yang lebih umum untuk menyimpulkan pengetahuan yang lebih khusus. Dengan melihat, mendengar, dan mengalami dari orang-orang di sekitar, akal seseorang menjadi sadar akan adanya orang-orang dan objek-objek yang diresepsi itu, sadar pula akan dirinya sendiri. Hal itu juga dilakukan oleh subjek penelitian. Mereka berkesempatan untuk menemukan dan menerapkan pendapat sendiri dan orang lain untuk mencapai tingkat pemahaman yang lebih tinggi. Mereka belajar melalui kehidupan nyata dengan cara menemukan dan mengeksplorasi sesuatu yang baru.

Temuan pengajuan pendirian, pembuktian, dan penyimpulan erat kaitannya dengan pengetahuan awal yang tersimpan dalam memori jangka panjang (LTM) pada setiap orang. Clark \& Clark (1977:135) menyatakan bahwa secara teoretis LTM menyimpan dua jenis informasi, yaitu informasi episodik dan pengetahuan umum, informasi episodik meliputi fakta tentang kehidupan sehari-hari yang mempunyai limitasi dari segi substansi, bentuk, dan fungsinya. Pengetahuan umum meliputi fakta dan generalisasi yang tidak mempunyai limitasi sebagaimana informasi episodik. Termasuk dalam pengetahuan umum ini sistem budaya (nilai, orientasi, dan persepsi) masyarakat sebagai ekosistem sosial seseorang. Kesesuaian pengetahuan awal dalam konteks penelitian ini, subjek penelitian menggunakan pengetahuan awal untuk memahami, menginterpretasi, dan menilai fenomena alam dan sosial yang ada di sekitar mereka. Mereka mengaitkannya dengan skemata yang mereka miliki dalam mengajukan pendirian, pembuktian, dan penyimpulan yang termuat dalam WAT yang dihasilkan.

\section{SIMPULAN}

Tipe argumen WAT siswa SD kelas tinggi dibedakan (1) pendirian, (2) pembuktian, dan (3) penyimpulan. Tipe argumen yang disampaikan WAT siswa SD kelas tinggi disertai dengan contoh-contoh untuk membuktikan agar argumen yang disampaikan dapat diterima oleh pembaca. Ketiga tipe argumen tersebut dipaparkan berikut. 
Pendirian dalam WATSD kelas tinggi didasarkan pada (1) pendirian faktual, (2) interpretatif, dan (3) evaluatif. Pendirian faktual ditandai dengan pernyataan tentang fakta dan data-data konkret. Pendirian interpretatif menjelaskan pendapat tentang kejadian atau keadaan dapat meliputi pertimbangan tentang masalah-masalah sebagai sebab dan akibat konteks tertentu.Pendirian evaluatif menjelaskan tentang penilaian keefektifan sebuah pernyataan.

Pembuktian dalam WATSD kelas tinggi merujuk pada proses pengajuan bukti untuk mendukung sebuah argumen agar gagasan yang disampaikan mudah diterima oleh mitratutur. Pembuktian didasarkan pada pengamatan terhadap objek dan berdasarkan pengetahuan umum. Pembuktian berdasarkan hasil pengamatan dilakukan oleh para siswa melalui kegiatan mendengar, melihat, atau merasakannya. Pembuktian berdasarkan pengetahuan umum merujuk pada asumsi bahwa orang mempercayai fakta bersumber dari deskripsi naratif tentang objek atau kejadian yang dikumpulkan dan disusun secara sistematis dan informatif yang membantu meningkatkan argumen agar gagasan yang disampaikan dapat diterima oleh pembaca.

Penyimpulan dalam WAT siswa SD kelas tinggi adalah proses mendapatkan suatu proposisi yang ditarik dari satu atau lebih proposisi. Penyimpulan dilakukan secara induktif dan deduktif. Penyimpulan induktif, simpulannya lebih umum daripada premis-premisnya. Penyimpulan deduktif, simpulan tidak mungkin lebih umum sifatnya daripada premis-premisnya.

Berdasarkan penyimpulan hasil penelitian tipe argumen dapat dirumuskan proposisi ilmiah, yaitu tipe argumen WAT siswa SD kelas tinggi berupa pendirian tentang fakta, pembuktian berdasarkan pengamatan dan pengalaman, serta penyimpulan induktif dan deduktif menun- jukkan kekonkretan berpikir siswa usia SD.

\section{UCAPAN TERIMA KASIH}

Artikel ini merupakan bagian dari disertasi saya. Oleh karena itu, saya mengucapkan terima kasih kepada Prof. Dr. Dawud, M.Pd. selaku promotor. Ucapkan terima kasih juga ditujukan kepada tim redaksi jurnal Litera yang telah memberi masukan guna perbaikan artikel dan memberi kesempatan untuk diterbitkan di jurnal ini.

\section{DAFTAR PUSTAKA}

Brooks, C. \& Warrant, R.P. 1949. Modern Rethoric. New York: Harcourt, Brace Company.

Chomsky, N. 1965. Aspects of The Theory of Syntax Noam Chomsky. Cambridge: The M.I.T Press.

Clark, H.H. \& Clark, E.V. 1977. Psychology and Language. San Diego: Harcourt Barce Javanovich Publishers.

Copi, I.M \& Cohen, C. 1990. Introduction of Logic. New York: Macmillan College Publishing Company.

Dawud. 1998. "Penalaran pada Tuturan Bahasa Indonesia Siswa Sekolah Dasar". Disertasi. Malang: IKIP Malang.

Dawud. 2010. “Pembelajaran Berargumentasi Tulis Bahasa Indonesia". Pidato Pengukuhan Guru Besar. Disampaikan pada Sidang Terbuka Senat Universitas Negeri Malang, 30 September 2010. Malang: Universitas Negeri Malang.

Depdiknas. 2006.Kurikulum Tingkat Satuan Pendidikan: Mata Pelajaran Bahasa dan Sastra Indonesia: Sekolah Dasar. Jakarta: Depdiknas.

Fisher, R. 1993. Teaching Children to Think. Maylands Eenue: Simon and Schuster Education.

Holsti, O.R. 1969. Content Analysis for the Social Sciences and Humanities. Reading: Addison-Wesley. 
Keraf, G. 2010. Argumentasi dan Narasi. Jakarta: Gramedia Pustaka Utama.

Krippendorff, K. 1980. Content Analysis: an Introduction to its Methodology. Beverley Hills, CA. Sage.

Mehra, P.S. dan Burhan, J. 1988. Pengantar Logika Tradisional. Bandung: Bina Cipta.

Poespoprodjo, W. dan Gilarso, T. 1999. Logika Ilmu Menalar. Bandung: Pustaka Grafika.
Santoso, A. 1995. "Penalaran sebagai Transaksi Kritis" dalam Jurnal Pendidikan Humaniora dan Sains. Tahun 1 (2): 56-64

Santoso, A. 2002. "Penggunaan Bahasa Indonesia dalam Wacana Politik Pasca Era Orde Baru". Disertasi. PPS Universitas Negeri Malang 